\title{
HDAC Inhibitor AR-42
}

National Cancer Institute

\section{Source}

National Cancer Institute. HDAC Inhibitor AR-42. NCI Thesaurus. Code C116850.

An orally available phenylbutyrate-derived histone deacetylase (HDAC) inhibitor, with potential antineoplastic activity. Upon oral administration, AR-42 inhibits the catalytic activity of HDAC, which results in an accumulation of highly acetylated chromatin histones, the induction of chromatin remodeling and an altered pattern of gene expression. This leads to the inhibition of tumor oncogene transcription, and the selective transcription of tumor suppressor genes, which inhibits tumor cell division and induces tumor cell apoptosis. HDAC, an enzyme upregulated in many tumor types, deacetylates chromatin histone proteins. 